\title{
PENGEMBANGAN SISTEM INFORMASI AKADEMIK UNIVERSITAS PAHLAWAN TUANKU TAMBUSAI RIAU
}

\author{
Indra Irawan \\ Program Studi Pendidikan Guru Sekolah Dasar, Fakultas Ilmu Pendidikan \\ Universitas Pahlawan Tuanku Tambusai(UPTT) \\ Jl. Tuanku Tambusai No.23 Bangkinang Kampar \\ E-mail : indrairawan@universitaspahlawan.ac.id
}

\begin{abstract}
Abstrak
Kemudahan, keakuratan dan tepat waktu merupakan alasan kenapa teknologi informasi dibutuhkan saat ini walau hal ini membutuhkan biaya yang besar dari sisi pengadaannya. Hal ini juga yang menjadi alasan kenapa Universitas Pahlawan memanfaatkannya untuk memberikan pelayanan kepada para mahasiswa dan memberikan kemudahan bagi karyawannya dalam bidang administrasi akademik. sebagai satu-satunya universitas di Kabupaten Kampar dan letaknya yang begitu dekat dengan ibukota Propinsi Riau yang merupakan pusat pendidikan di kawasan ini, sudah menjadi keharusan bagi pihak kampus untuk meningkatkan pelayanannya dalam upaya meningkatkan daya saing dengan institusi pendidikan lainnya. Salah satunya ialah dengan menerapkan Pengembangan Sistem Informasi Akademik berbasis Teknologi Informasi menggunakan jaringan Local Area Network(LAN) berbasis TCP/IP, menggunakan bahasa pemrograman Visual Basic 6.0, dan untuk sistem databasenya menggunakan Ms.SQL Server 2000. Dengan segenap kemudahan dan keunggulan yang ditawarkannya diharapkan dapat memberikan kontribusi dan nilai tambah bagi Universitas Pahlawan untuk turut serta dalam mencerdaskan kehidupan bangsa kita ini.
\end{abstract}

Kata kunci : Sistem Informasi Akademik

\section{PENDAHULUAN}

Sebagai satu-satunya universitas yang baru berdiri di kawasan Kabupaten Kampar dan letaknya yang sangat berdekatan dengan ibukota Propinsi Riau yang memiliki lembaga pendidikan yang lebih banyak dan berkualitas, sudah seharusnya universitas pahlawan terdorong untuk lebih meningkatkan kualitasnya dikarenakan ketatnya persaingan dengan lembaga pendidikan yang lainnya. Salah satu upaya peningkatan pelayanannya kepada masyarakat ialah dengan menerapkan sistem informasi akademik berbasis komputer bagi para mahasiswanya, sehingga informasi yang dihasilkan lebih cepat bisa diakses dan lebih akurat.

Penggunaan perangkat teknologi informasi dalam memberikan pelayanan terhadap kebutuhan akan akses informasi yang dalam hal ini adalah informasi akademik adalah hal mutlak diperlukan. Untuk itulah sebagai langkah awal pihak manajemen universitas pahlawan merubah tata cara akses dan pemberian informasi kepada para mahasiswanya dari cara-cara yang manual kepada penggunaan perangkat teknologi berbasis komputer dengan memanfaatkan jaringan lokal(LAN) dan penggunaan bahasa pemrograman berbasis desktop sehingga hal ini dapat membantu mempermudah pekerjaan pihak administrasi dan juga memudahkan mahasiswa dalam mendapatkan pelayanan administrasi akademik dari pihak universitas dengan melakukan akses ke sistem informasi yang disediakan dengan 
menggunakan terminal akses berupa komputer PC yang disediakan Unit Pusat komputer.

Sistem Informasi Akademik merupakan sebuah sistem yang dibangun dengan tujuan untuk mengelola data-data akademik dan segala kegiatan administrasi perkuliahan mahasiswa sehingga dapat memberikan kemudahan bagi pengguna dalam kegiatan administrasi akademik kampus secara online. Sistem Informasi Akademik merupakan salah satu dari berbagai sistem yang ada di Lingkungan Kampus.

\section{TINJAUAN PUSTAKA}

\subsection{Pengertian Sistem, Informasi dan Sistem Informasi}

Menurut Novi Nuari(2014) "Sistem adalah suatu jaringan kerja dari prosedur prosedur yang saling berhubungan, berkumpul bersama sama untuk melakukan suatu kegiatan atau untuk menyelesaikan suatu sasaran yang tertentu".

Menurut Yunita Adhawiyah dkk(2017) "Sistem dapat didefinisikan sebagai kumpulan komponen-komponen yang bekerja sama untuk tujuan bersama". Misalnya bidang organisasi keuangan, operasi dan pemasaran memiliki tujuan yang sama untuk mencapai tujuan perusahaan secara keseluruhan. Hal ini dapat dilihat bahwa dalam sistem, data digunakan sebagai input untuk diproses yang menghasilkan informasi sebagai output.

Kemudian pengertian dari informasi ialah "kumpulan dari beberapa fakta yang terorganisasi dan telah diproses agar memiliki nilai tambah selain nilai-nilai individual". Nilai dari informasi tersebut diantaranya bagaimana membantu pembuat keputusan mencapai tujuan organisasi mereka. Dapat membantu orang dalam organisasi melakukan tugas-tugas dengan efisien dan efektif.

Menurut Novi Nuari(2014) Sistem Informasi adalah "Suatu sistem terintegrasi yang mampu menyediakan informasi yang bermanfaat bagi penggunanya atau Sebuah sistem terintegrasi atau sistem manusia-mesin, untuk menyediakan informasi untuk mendukung operasi, manajemen dalam suatu organisasi”.

Menurut Ade bastian dkk(2017) Sistem informasi merupakan "suatu sistem di dalam organisasi yang mempertemukan kebutuhan pengolahan transaksi harian, mendukung operasi, bersifat manajerial dan kegiatan strategi dari suatu organisasi dan menyediakan pihak luar tertentu dengan laporan-laporan yang diperlukan".

\subsection{Pengertian Sistem Informasi Akademik}

Menurut Novi Nuari(2014) Sistem Informasi Akademik (SIAKAD) adalah aplikasi atau sistem yang dirancang dan dibuat untuk mengelolah data-data yang berhubungan dengan informasi akademik, meliputi data mahasiswa, data dosen, rekaman hasil kuliah, kurikulum dan jadwal perkuliahan.

\subsection{Pengertian Data Flow Diagram(DFD)}

Menurut Sukamto dkk dalam Ermatita(2016) "Data Flow Diagram (DFD) adalah representasi grafik yang menggambarkan aliran informasi dan transformasi informasi yang diaplikasikan sebagai data yang mengalir dari masukan (input) dan keluaran (output)".

\subsection{Jaringan komputer}

Menurut Dwi Oktarina dan Jimmy Halim(2017) .Jaringan komputer adalah sekumpulan peralatan atau komputer yang saling dihubungkan untuk berbagi sumber daya.

Berdasarkan karaterianya dapat dibedakan menjadi 4 bagian: 
1. Berdasarkan jangkauan geografis dibedakan menjadi:
a. Jaringan LAN
b. Jaringan WAN

2. Berdasarkan distribusi sumber informasi/data dibedakan menjadi :
a. Jaringan terpusat
b. Jaringan terdistribusi

3. Berdasarkan media transmisi data dibedakan menjadi:

a. Jaringan Berkabel (Wired

b. Jaringan Nirkabel (Wireless Network)

4. Berdasarkan peranan Komputer dalam Proses Data
a. Jaringan Client-Server
b. Jaringan Peer-to-peer

\section{METODE PENELITIAN}

Penelitian yang Penulis lakukan ini penelitian ini merupakan metode penelitian terapan, hal ini dikarenakan penelitian adalah untuk mendapatkan informasi yang dapat memecahkan permasalahan.

\subsection{Teknik Pengumpulan Data}

Adapun teknik yang penulis gunakan dalam penelitian ini ialah :

1. Observasi

Pengumpulan data dengan pengamatan secara langsung kelokasi penelitian dan mengamati mekanisme kerja pada kampus Universitas Pahlawan berkaitan dengan sistem informasi akademik.

2. Wawancara

Teknik ini penulis lakukan dengan cara melakukan Tanya jawab dengan pegawai kampus yang terlibat dalam sistem ini

3. Studi Pustaka

Berupa mencari literatur dari jurnal-jurnal yang terkait dengan topik yang penulis bahas dalam penelitian ini

4. Dokumentasi

Mendokumentasikan hasil penelitian penulis sehingga bisa dijadikan referensi bagi penelitian selanjutnya

\subsection{Perancangan Program}

Perancangan program terdiri dari beberapa tahapan :

1. Pengkodean

Membuat Aplikasi dengan menggunakan bahasa pemrograman Visual Basic 6.0 dan menggunakan DBMS SQL Server 2000

2. Pengujian

Melakukan testing atau pengujian aplikasi setelah melakukan pemasangan instalasi jaringan Lokal dan melakukan perbaikan terhadap kesalahan berupa eror atau kendala yang lainnya

3. Implementasi

Menerapkan dan menjalankan sistem setelah dilakukan perbaikan

4. Evaluasi

Melakukan observasi setelah sistem dijalankan dalam waktu rentang tertentu 


\section{HASIL DAN PEMBAHASAN}

4.1 Arsitektur Jaringan Sistem Informasi Akademik

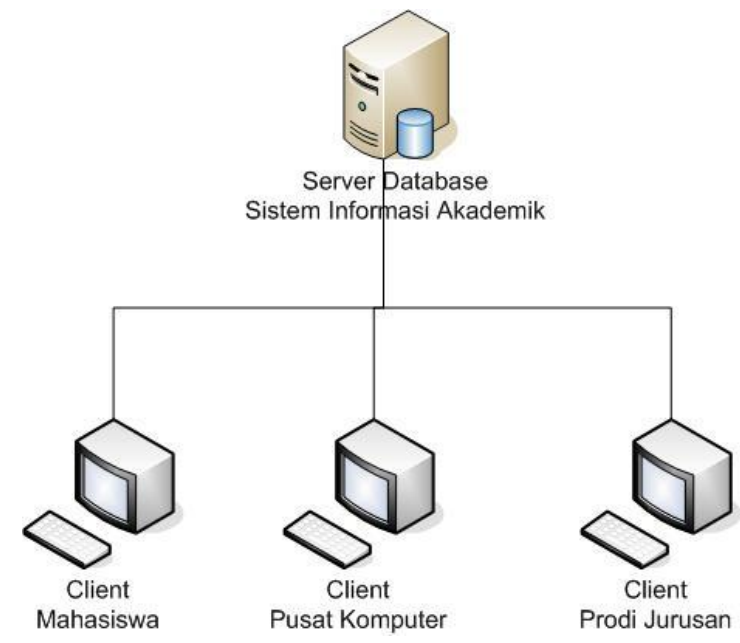

Gambar 4.1 : Arsitektur Jaringan Komputer Sistem Informasi Akademik UP

\subsection{Alur Sistem Informasi Lama}

Analisa sistem informasi lama merupakan suatu proses penguraian dari suatu sistem informasi yang utuh kedalam bagian-bagian komponennya dengan maksud untuk mengidentifikasi dan mengevaluasi segala hambatan-hambatan, kesempatan-kesempatan dan permasalahan yang terjadi serta kebutuhan yang diharapkan sehingga dapat diusulkan perbaikannya. 


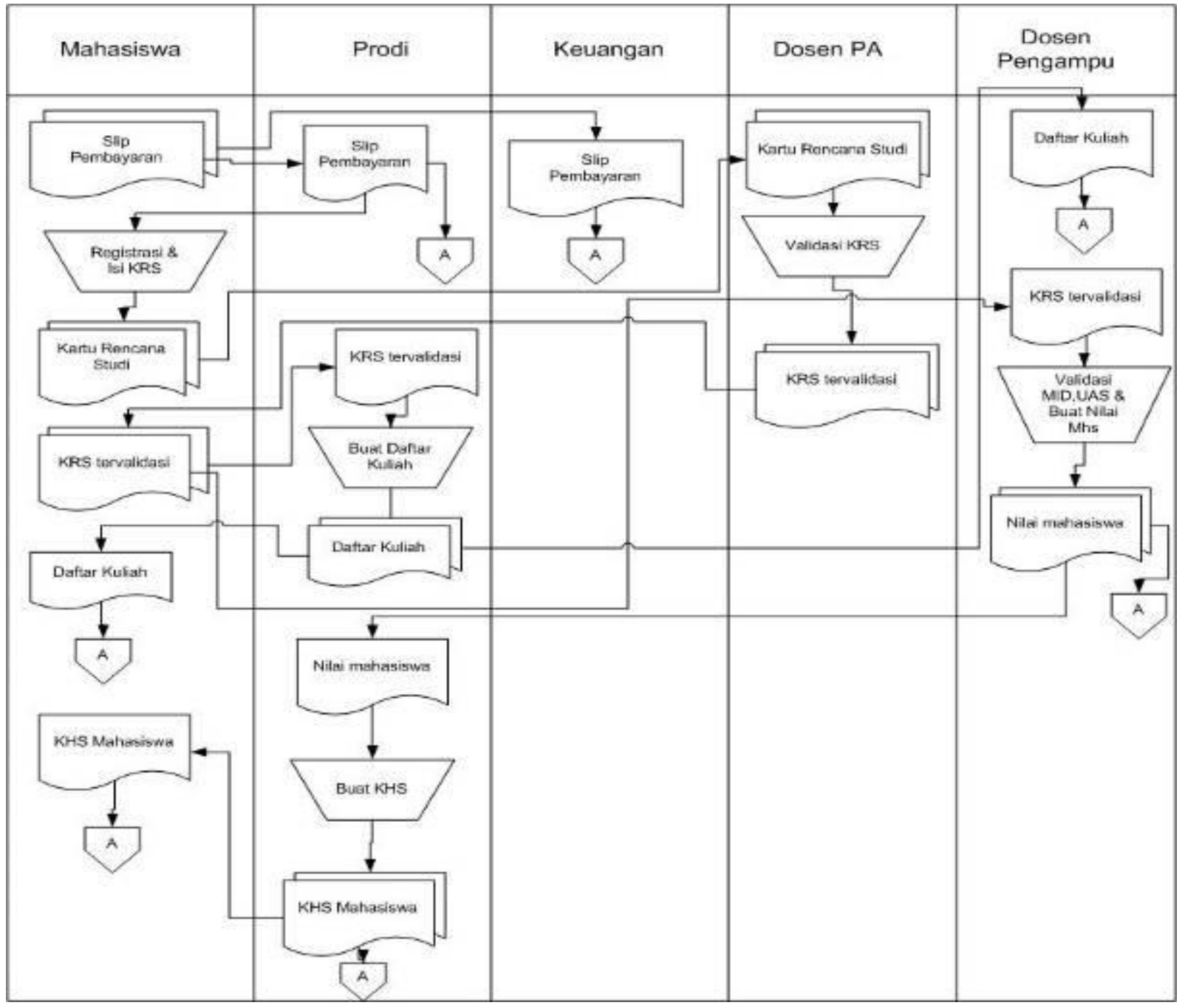

Gambar 4.2 : Alur Sistem Informasi yang Lama

\subsection{Alur Sistem Informasi yang diusulkan}

Berikut adalah Alur Sistem Informasi yang baru diusulkan : 


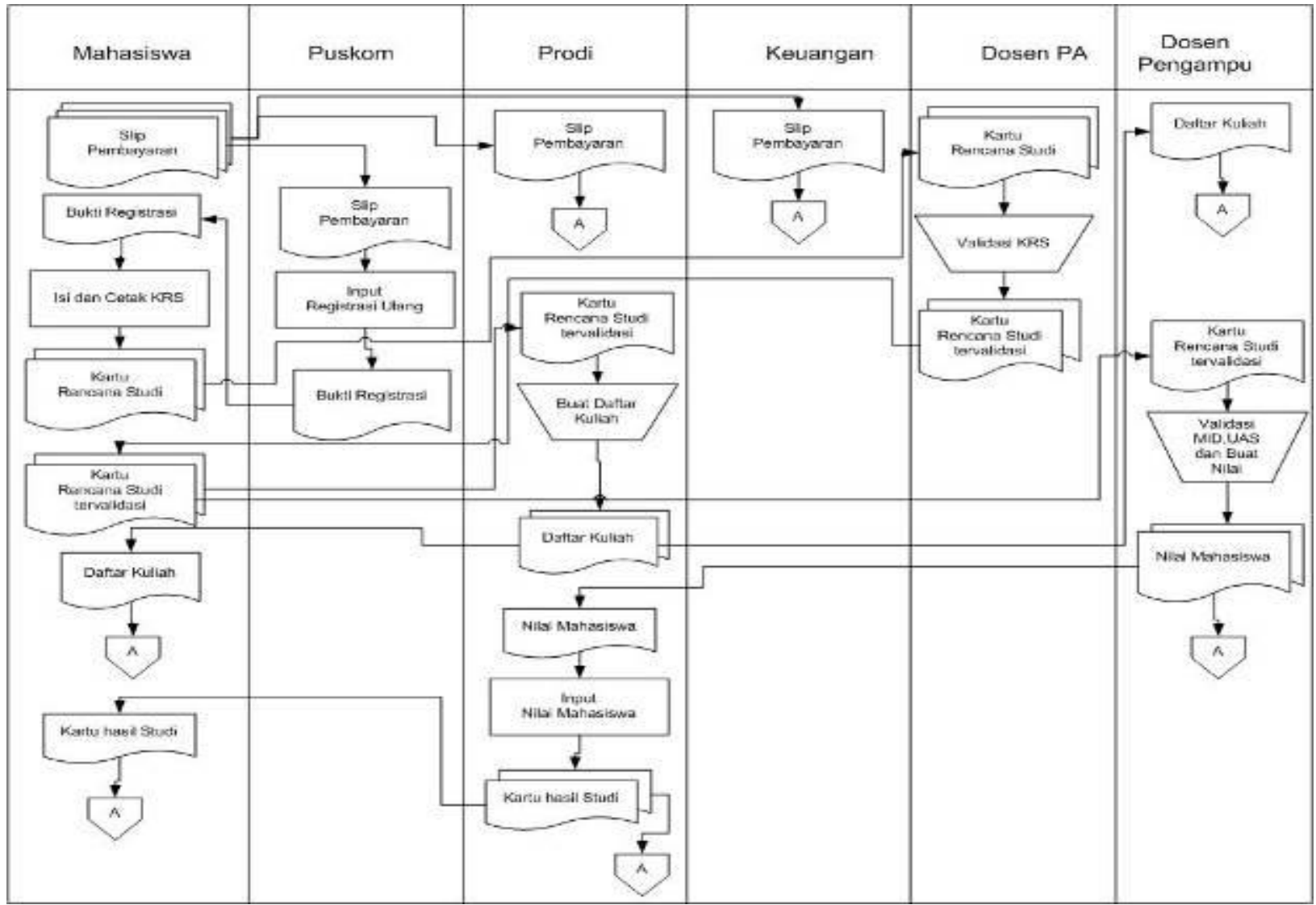

\section{Penjelasan}

Gambar 4.3 : Alur Sistem Informasi yang baru

Dari gambar Alur Sistem Informasi yang baru diatas dapat dilihat bagaimana penggunaan computer sudah dilakukan dalam penginputan data sehingga proses untuk mendapatkan output yang dihasilkan berupa KHS lebih cepat dihasilkan

\subsection{Context Diagram}

Berikutnya adalah Context Diagram dari Sistem Informasi yang baru diusulkan :

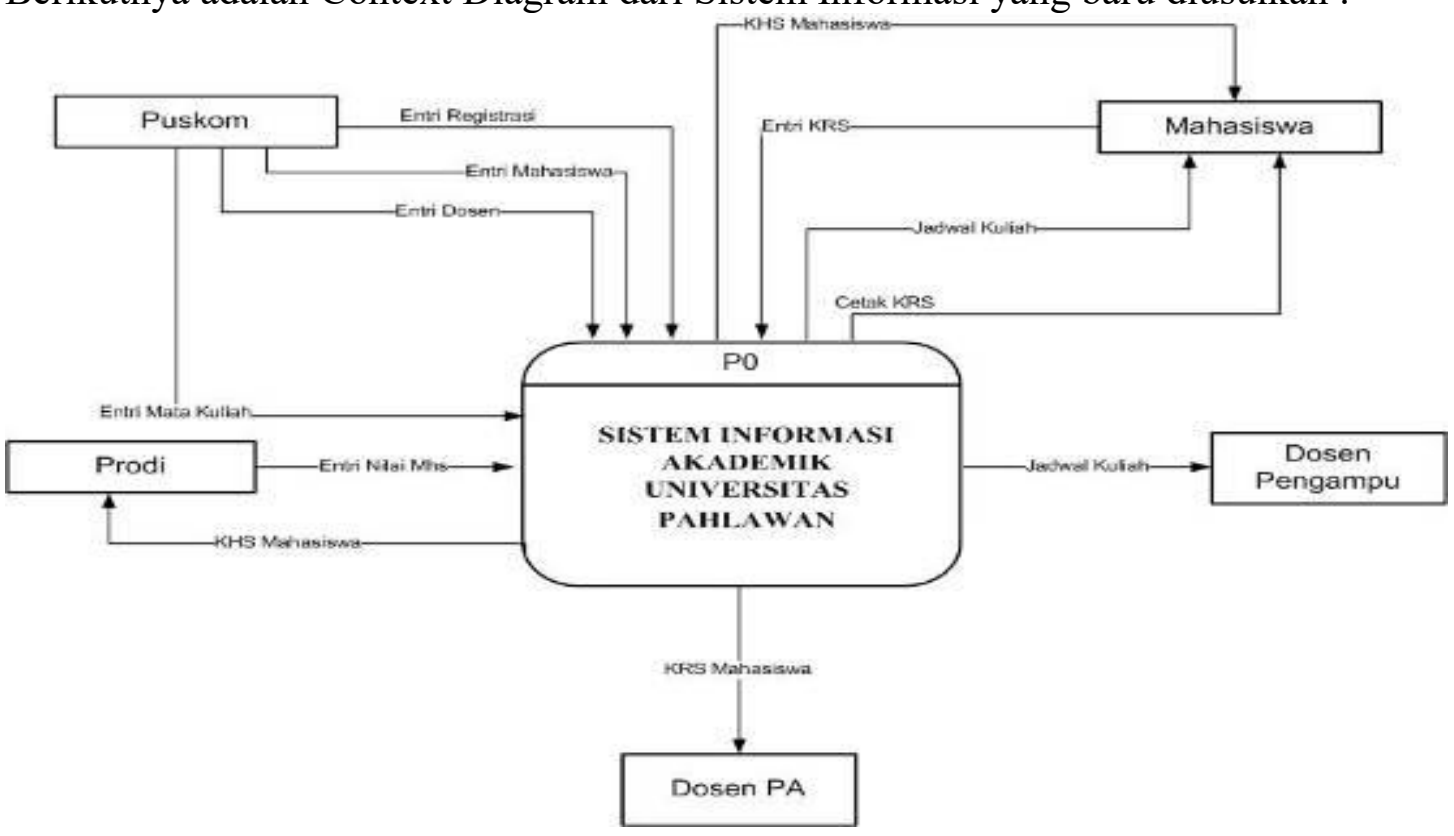

Gambar 4.4 : Context Diagram 


\subsection{Data Flow Diagram}

DFD untuk sistem baru dapat dilihat pada gambar-gambar di bawah ini:

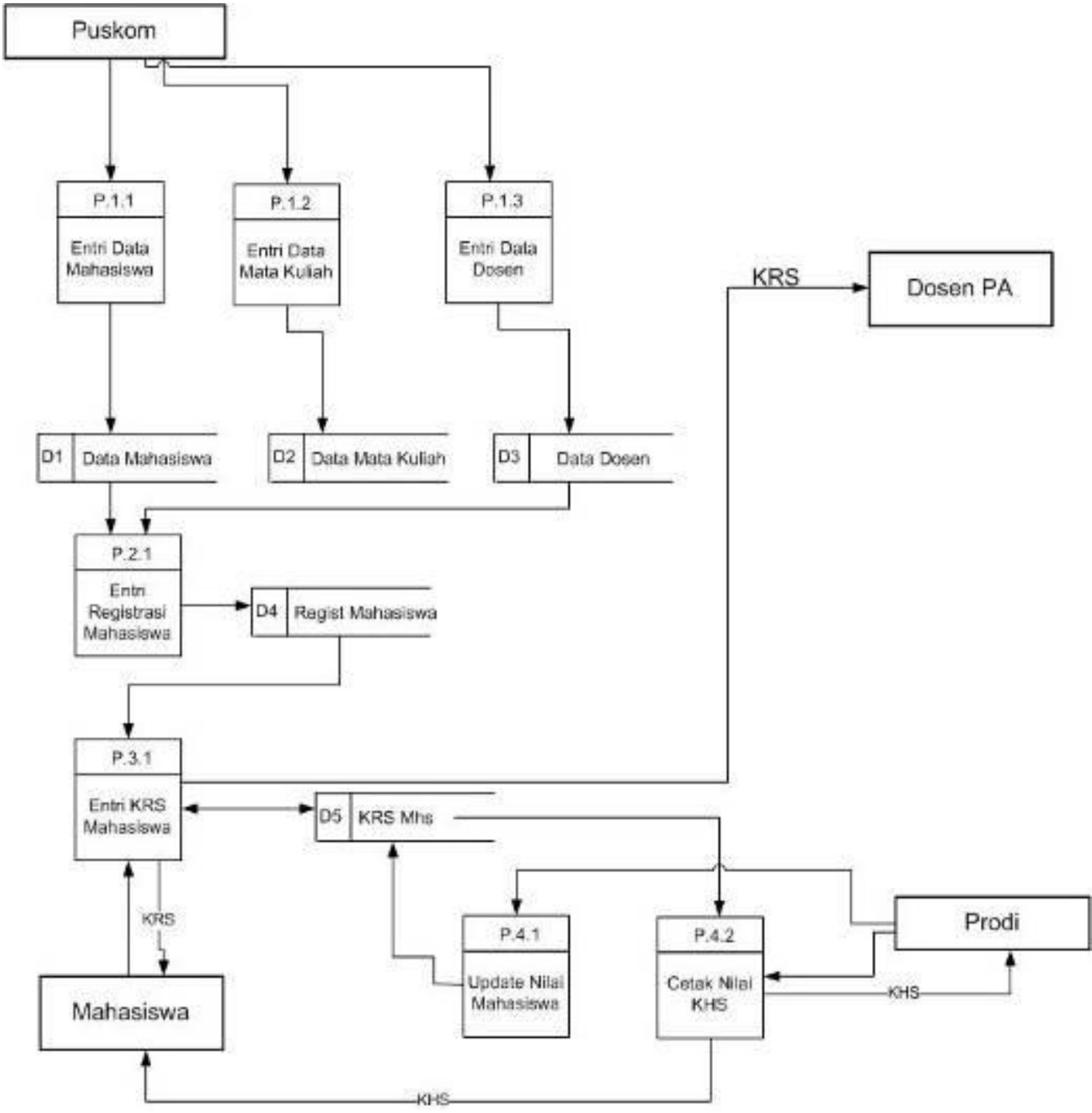

Gambar 4.5 : Data Flow Diagram Level 1 dari Sistem yang Diusulkan

\subsection{Hasil Rancangan Program}

Berikut ini merupakan beberapa halaman form aplikasi yang dihasilkan dari Perancangan Sistem Informasi ini: 


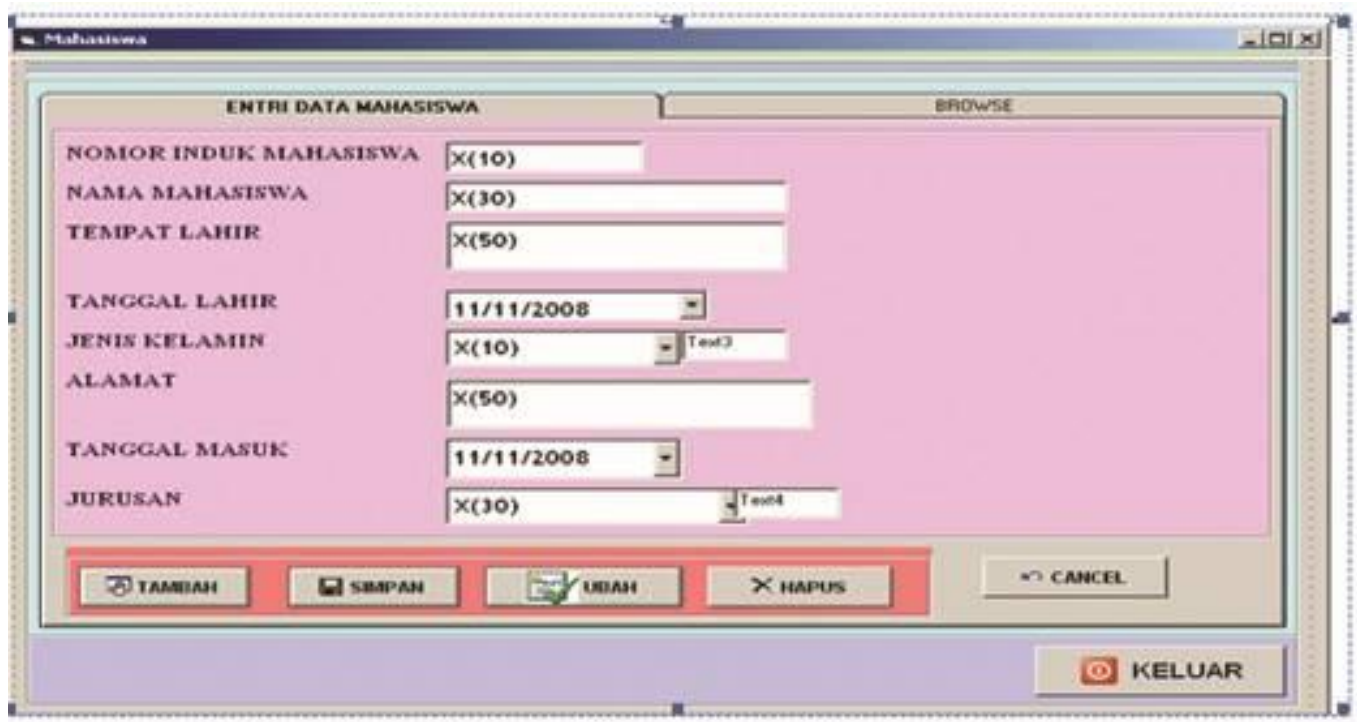

Gambar 4.6 : Lay out Form Input Data Mahasiswa

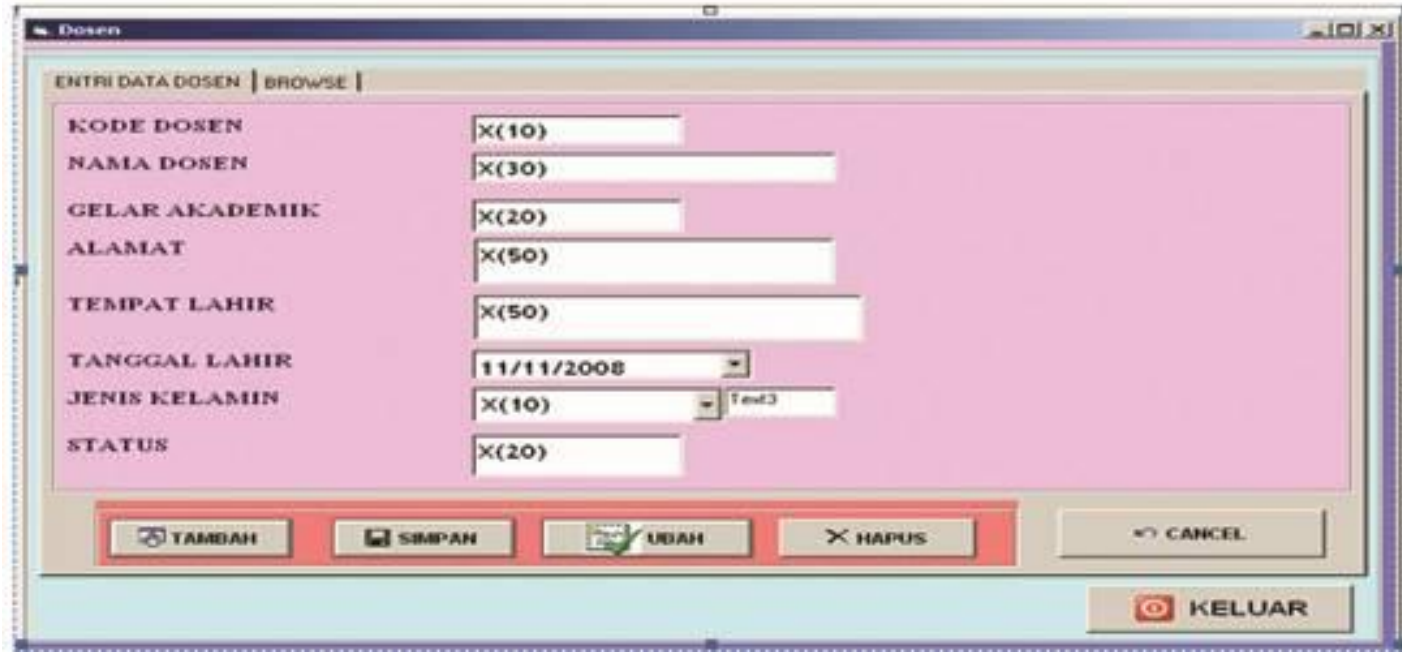

Gambar 4.7 : Lay out tampilan input Data Dosen

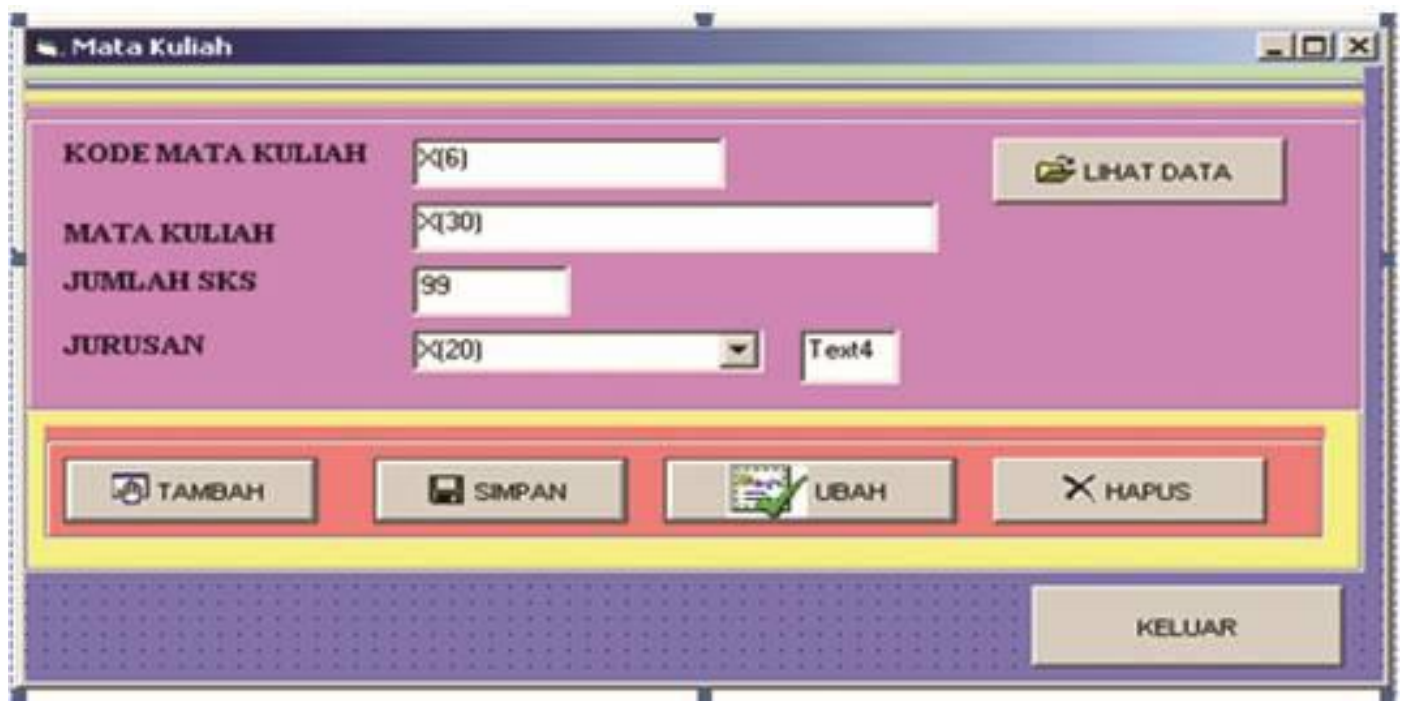

Gambar 4.8 : Lay out tampilan input Data Mata Kuliah 


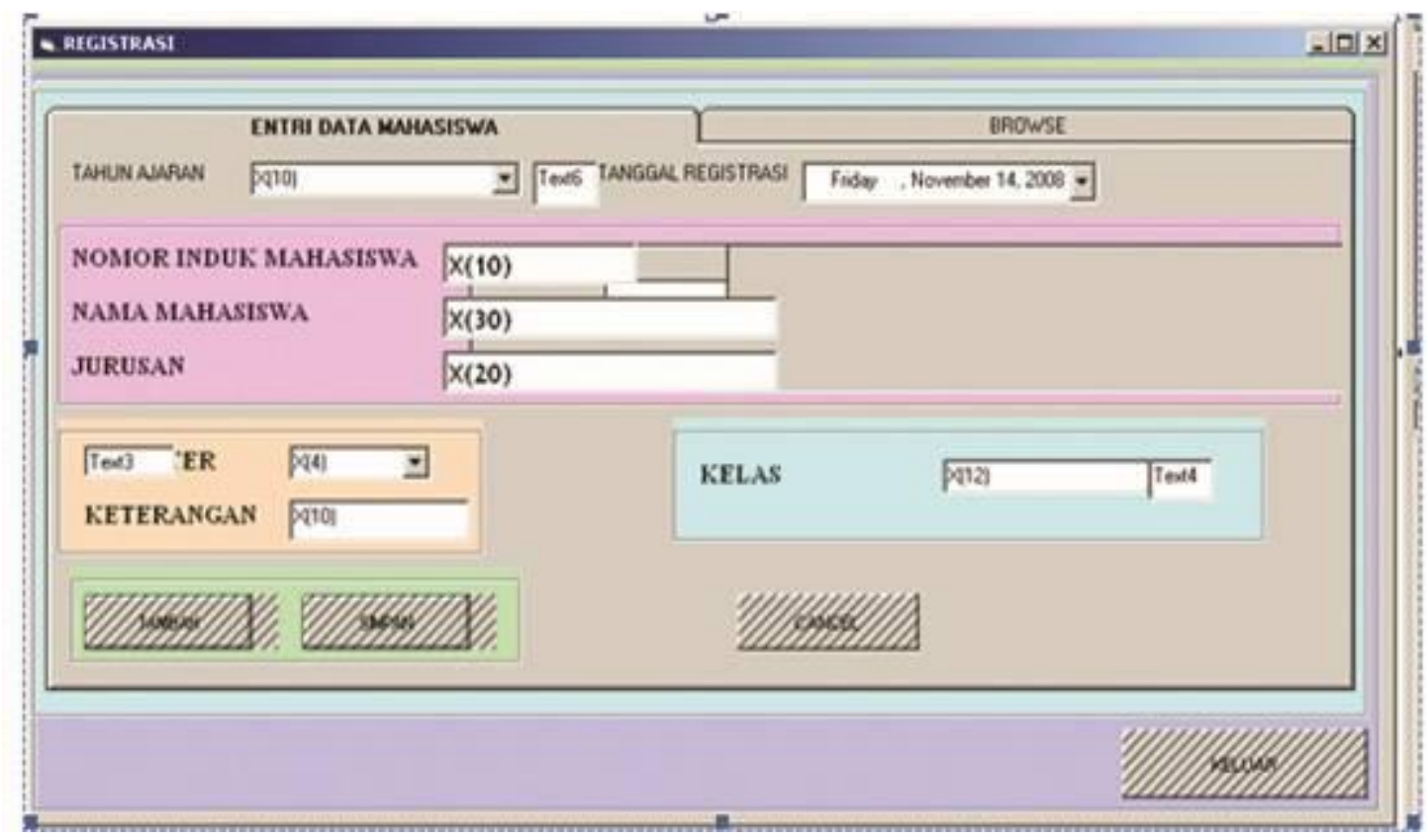

Gambar 4.9 : Lay out tampilan input Data Registrasi Mahasiswa

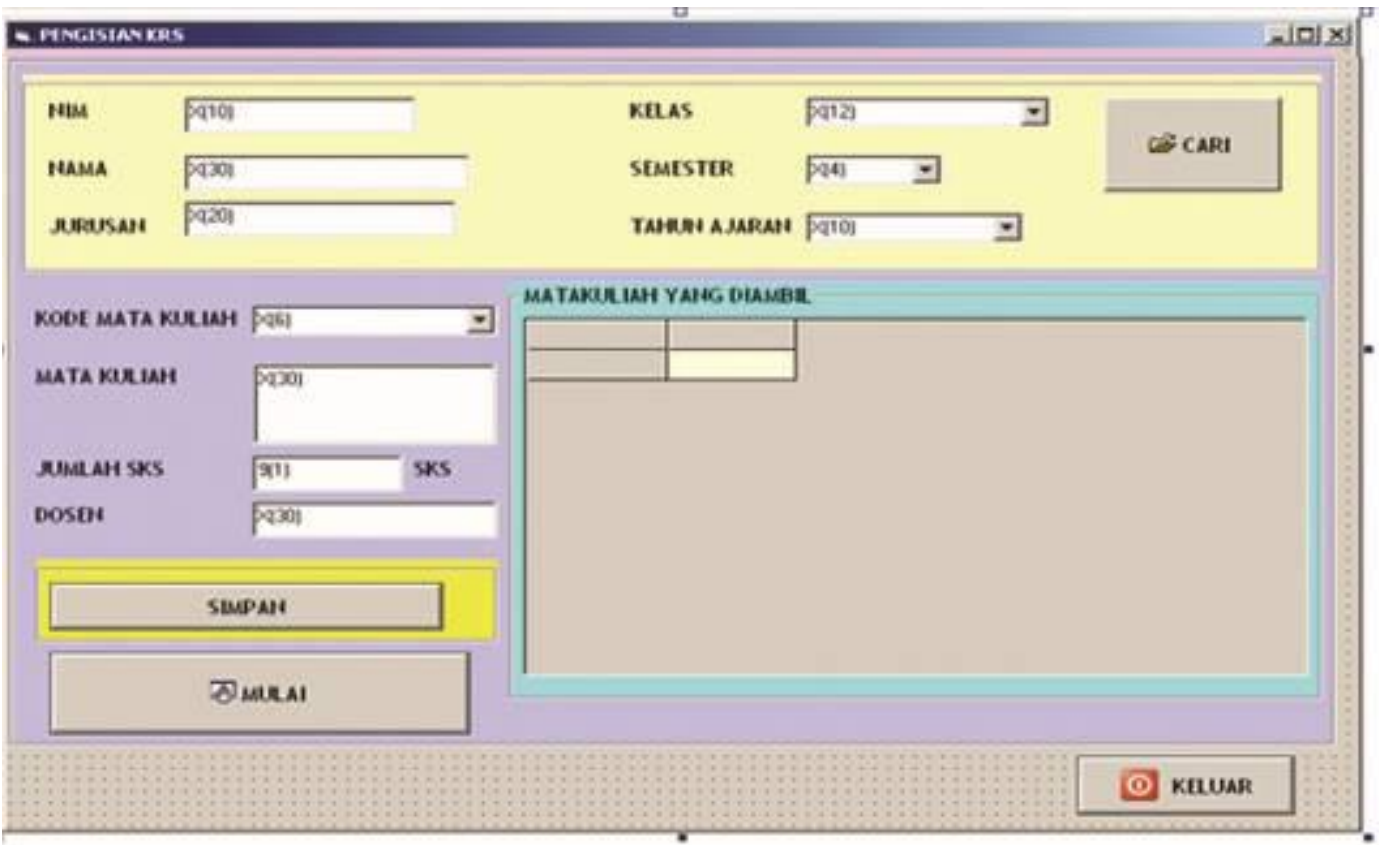

Gambar 4.10 : Lay out tampilan input Data KRS 


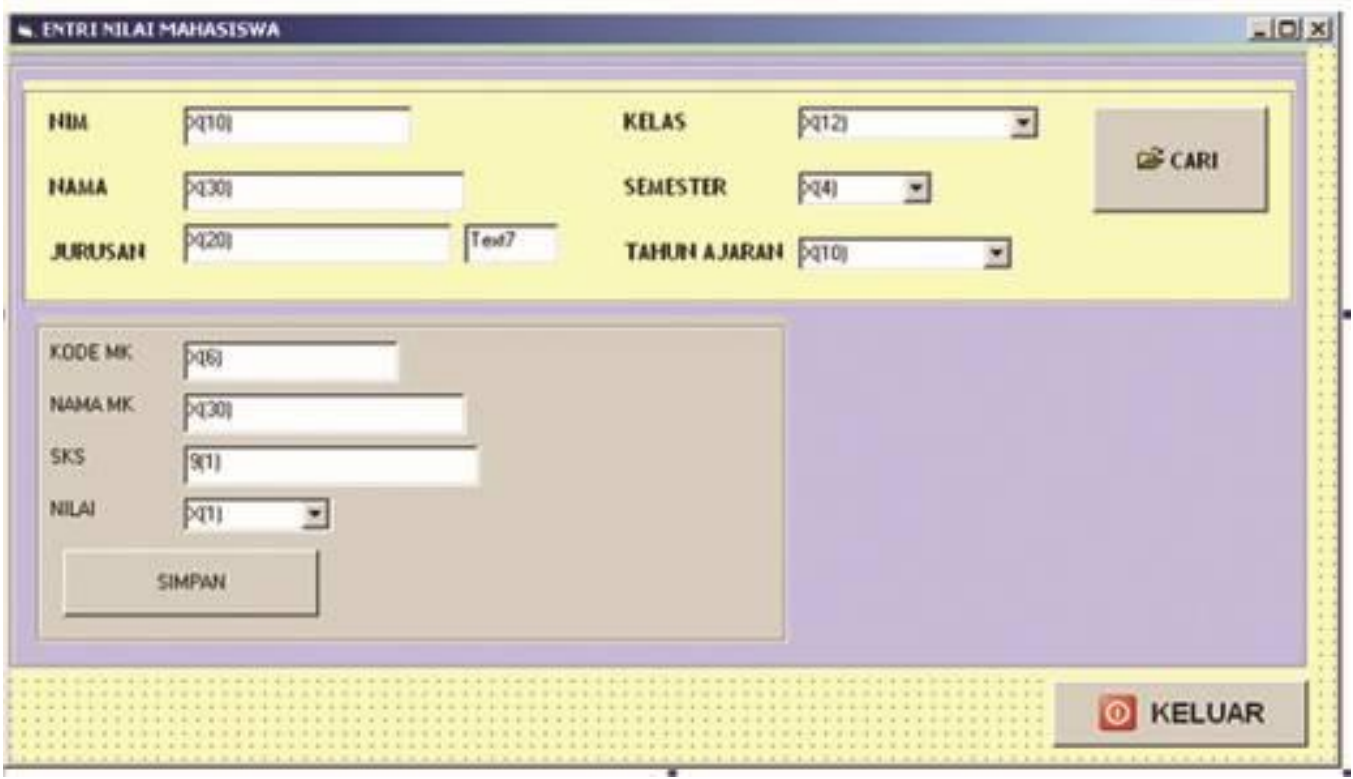

Gambar 4.11 : Lay out tampilan input Nilai Mahasiswa

\section{UNIVERSITAS PAHLAWAN}

TUANKU TAMBUSAI RIAU

\section{KART U RENCANA STUDI}

$\begin{array}{llll}\text { Nama } & \text { MURNLATI CHANIAGO } & \text { NIMI } & 0803189012 \\ \text { Kelas } & \text { Siang } & \text { Tahun } & 1998.1999 \\ \text { Semester } & \text { I } & \text { Nm_Jurusan } & \text { Teknik Informatika }\end{array}$

\begin{tabular}{|l|l|l|c|l|}
\hline No & KODE & MATA KULIAH & SKS & \multicolumn{1}{c|}{ DOSEN } \\
\hline & KK0109 & Kalkulus & 2 & Edwar Ali \\
\hline & KK0123 & Metode Numerik & 3 & MEFA INDRIATI \\
\hline & KKL 021 & Sistem Pakar & 2 & MEFA INDRIATI \\
\hline & KK8976 & Statistik Desknitif & 2 & Edwar Ali \\
\hline & KKBRD0 & BORLAND DELPHI & 2 & RAHMIATI \\
\hline & KK0098 & Visual Basic 1/ Basic Vissal One & 2 & Edwar Ali \\
\hline
\end{tabular}

Disetujui Oleh

Dosen Penasehat Akademis

Nama \& Paraf

\section{Bangkinang,}

Mahasiswa Ybs,

Robi Sagara

Gambar 4.12 : Lay out tampilan Output KRS 


\section{UNIVERSITAS PAHLAWAN TUANKU \\ TAMBUSAI RIAU}

\section{KART U HASIL STUDI}

\begin{tabular}{|c|c|c|c|c|c|c|c|}
\hline \multirow{3}{*}{$\begin{array}{l}\text { Nama } \\
\text { Kelas } \\
\text { Semester }\end{array}$} & \multicolumn{2}{|c|}{ MURNIATI CHANIAGO } & NIM & \multicolumn{3}{|c|}{0803189012123} & \\
\hline & \multicolumn{2}{|c|}{ Siang } & Tahun & \multicolumn{3}{|c|}{$1998-1999$} & \\
\hline & \multicolumn{2}{|l|}{ I } & Nm_Jurusan & \multicolumn{3}{|c|}{ Teknik Informatika } & \\
\hline No & Kd_MK & Nama_MK & & SKS & Nilai & Bobot & Total \\
\hline 1 & KK0109 & Kalkulus & & 2 & A & 4 & 8 \\
\hline 2 & KK0123 & Metode Numerik & & 3 & B & 3 & 9 \\
\hline 3 & KKL 021 & Sistem Pakar & & 2 & A & 4 & 8 \\
\hline 4 & KK8976 & Statistik Deskriftif & & 2 & B & 3 & 6 \\
\hline 5 & KKBRD0 & BORLAND DELPFI & & 2 & c & 2 & 4 \\
\hline 6 & KK0098 & Visual Basic 1/Bassi & One & 2 & A & 4 & 8 \\
\hline \multicolumn{4}{|c|}{ TOTAL SKSYANG DIAMBIL SEME STER INI } & 13 & & & 43 \\
\hline \multicolumn{4}{|c|}{ IP SE MIESTER INI } & \multicolumn{4}{|c|}{3,31} \\
\hline \multicolumn{4}{|c|}{ SEME STER YANG AKAN DATANG } & \multicolumn{3}{|c|}{24} & \\
\hline
\end{tabular}

PEMBANTU REKTOR I

DWI ANGGRIANI, M.Keb

Gambar 4.13 : Lay out tampilan Output KHS Mahasiswa

\section{KESIMPULAN}

Berikut ini merupakan kesimpulan dari penelitian yang telah penulis lakukan :

1. Adanya sistem informasi akademik ini menjadikan informasi yang berkaitan dengan pelayanan akademik mahasiswa lebih cepat dan akurat sehingga hal ini mampu memberikan kepuasan lebih kepada para mahasiswa dari segi pelayanan administrasi perkuliahan.

2. Kesalahan yang sering muncul dari pemakaian sistem sebelumnya yang masih menggunakan cara-cara manual dapat diminimalisir sehingga hal ini merupakan nilai tambah dari pengembangan sistem yang baru ini.

\section{UCAPAN TERIMAKASIH}

Ucapan terima kasih penulis ucapkan kepada pihak yang telah membantu penulis dalam menyelesaikan penelitian ini, diantaranya Rektor Universitas pahlawan Prof. Dr. Amir Lutfi, Wakil Rektor I Ibu Dwi Anggriani Harahap M.Keb, Wakil Rektor II ibu Yusnira, M.Si, para dosen dan juga rekan-rekan di Puskom Universitas pahlawan yang tidak bisa penulis sebutkan satu persatu disini.

\section{DAFTAR PUSTAKA}

Novi Nuari, (2014). "Perancangan Aplikasi Layanan Mobile Informasi Administrasi akademik Berbasis Android Menggunakan Webservice". Jurnal Sistem dan Teknologi Informasi, Volume 2, No. 1, januari 2014, ISSN 2460-3562

Dwi Oktarina, Jimmy Halim, (2017). "Sistem Informasi Penjualan dengan Menerapkan Teknologi RFID”. Riau Journal Of Computer Science, Volume 3, No. 2, Juli 2017, ISSN 2460-0679 
Yunita Adhawiyah, Nia Kumaladewi, Meinarini Catur Utami, (2017). "Rancang Bangun Sistem Informasi Penilaian Kinerja Pegawai Menggunakan Metode Psycological Appraisal". Studia Informatika: Jurnal Sistem Informasi Vol. 2,No.10, oktober 2017, ISSN: 1979-0767.

Ade Bastian, Tri Ferga Prasetyo, Nia Kurniati, (2017). "Rancang Bangun Sistem Informasi Manajemen Peternak Ayam pada Koperasi Sinar Mulya Menggunakan Microsoft Visual Basic 2010.net”. Studia Informatika: Jurnal Sistem Informasi Vol. 2,No.10, oktober 2017, ISSN: 1979-0767.

Ermatita, (2016). "Analisis dan Perancangan Sistem Informasi Perpustakaan". Jurnal Sistem Informasi(JSI) Vol. 8,No.1, april 2016, ISSN: 2355-4614. 